Article

\title{
Preparation of Direct Reduced Iron and Titanium Nitride from Panzhihua Titanomagnetite Concentrate through Carbothermic Reduction-Magnetic Separation
}

\author{
Wen Yu ${ }^{1}$, Xiaojin Wen ${ }^{1}$, Jiangan Chen ${ }^{1}$, Jingzhong Kuang ${ }^{1}$, Qiongyao Tang ${ }^{2}$, Yuechao Tian ${ }^{1}$, \\ Jiali Fu ${ }^{1}$, Weiqin Huang ${ }^{1}$ and Tingsheng Qiu ${ }^{1, *}$ \\ 1 Faculty of Resource and Environmental Engineering, Jiangxi University of Science and Technology, \\ Ganzhou 341000, China; yuwenminer@163.com (W.Y.); xiaojinwen95@gmail.com (X.W.); \\ jachen@jxust.edu.cn (J.C.); qpowder@126.com (J.K.); tian1347222@gmail.com (Y.T.); \\ 18720724755@163.com (J.F.); huangweiqin0403@gmail.com (W.H.) \\ 2 School of Architectural and Surveying and Mapping Engineering, \\ Jiangxi University of Science and Technology, Ganzhou 341000, China; tangyaominer@163.com \\ * Correspondence: qiutingsheng@163.com; Tel.: +86-0797-831-2008
}

Received: 30 August 2017; Accepted: 6 November 2017; Published: 10 November 2017

\begin{abstract}
A novel process for preparing direct reduction iron (DRI) and titanium nitride (TiN) from Panzhihua titanomagnetite concentrate is proposed. This process involves pelletizing, direct reduction roasting and magnetic separation. The effects of reduction temperature, coal dosage and reduction time on the phase transformation of composite pellets were investigated by $\mathrm{X}$-ray diffraction. Results show that TiN formation proceeds less easily than metallic iron formation. Increasing the reduction temperature, reduction time and coal dosage can promote the transformation of titanium to TiN. Titanium was almost completely transformed into TiN under the conditions of $1300{ }^{\circ} \mathrm{C}$ reduction temperature, $26 \mathrm{wt} \%$ coal dosage and 90 min reduction time. The scanning electron microscopy (SEM) analysis showed that near-spherical metallic iron particles with diameters from dozens of microns to about $300 \mu \mathrm{m}$ were formed in the reduced pellets, whereas the TiN particles generally measured less than $10 \mu \mathrm{m}$. The energy dispersive spectroscopy (EDS) results revealed that the TiN phase contains a certain amount of vanadium and carbon, and traces of other impurities. The reduced composite pellets under the optimum conditions were processed by grinding and subsequent magnetic separation. As a result, a DRI with $92.88 \mathrm{wt} \% \mathrm{Fe}, 1.00 \mathrm{wt} \% \mathrm{Ti}$, and $0.13 \mathrm{wt} \% \mathrm{~V}$ was obtained, and the recoveries of $\mathrm{Fe}$, Ti, and $\mathrm{V}$ were $92.85 \mathrm{wt} \%, 9.00 \mathrm{wt} \%$, and $19.40 \mathrm{wt} \%$, respectively. $91.00 \mathrm{wt} \% \mathrm{Ti}$ and $80.60 \mathrm{wt} \% \mathrm{~V}$ were concentrated in the rough TiN concentrate.
\end{abstract}

Keywords: titanomagnetite; carbothermic reduction; magnetic separation; direct reduction iron; titanium nitride

\section{Introduction}

The Panzhihua titanomagnetite deposit is the largest titanomagnetite deposit in China, with a titanomagnetite reserve of 9.66 billion tons. The deposit accounts for $90.50 \mathrm{wt} \%$ of the titanium reserves in China [1]. Titanomagnetite and ilmenite concentrate are obtained from these ores by magnetic separation and flotation processes. Over the past decades, titanomagnetite concentrate was used as material for the blast furnace process in the Panzhihua area [2]. In this process, most of the iron and part of the vanadium can be recovered. However, almost all of the titanium compounds remain in the slag with $\mathrm{TiO}_{2}$ content varying from $22 \mathrm{wt} \%$ to $25 \mathrm{wt} \%$. To date, no appropriate and economical method has been found to address this kind of slag, because of the dispersed distribution of titanium in various fine-grained mineral phases $[1,3]$. Therefore, considerable attention has been 
focused on developing an alternative route for the comprehensive recovery of iron, titanium and vanadium from titanomagnetite.

The direct reduction process was developed to deal with the titanomagnetite concentrate [4-7]. In this process, the iron oxides are first reduced to metallic iron, while titanium oxides are rarely reduced. The reduced products are then separated by smelting or magnetic separation to produce iron and titanium slag. The resulting titanium slag generally contains $40 \mathrm{wt} \%$ to $50 \mathrm{wt} \% \mathrm{TiO}_{2}$. This content is much higher than that of the titanium slag produced by the blast furnace process. However, this titanium slag is still not a qualified raw material for the production of titanium dioxide because of the slag's high impurity content and low reactivity [1]. To date, the direct reduction process of titanomagnetite has not achieved large-scale industrialisation.

Recently, several studies have been conducted on the preparation of iron-based wear-resistant material from titanomagnetite concentrate through a carbothermal process, in which iron oxides are reduced to metallic iron while titanium oxides are transformed into $\operatorname{TiC}$ or $\operatorname{Ti}(\mathrm{C}, \mathrm{N})[8,9]$. However, all impurities in titanomagnetite concentrate and reductant remain in the prepared material which will degrade its performance.

A new process for preparing DRI and TiN from titanomagnetite concentrate was proposed by our laboratory. In this process, titanomagnetite concentrate was first reduced by coal to metallic iron and $\mathrm{TiN}$, and then separated by magnetic separation. In the next step, the TiN-enriched product was refined to produce TiN material. TiN has a high melting point $\left(2950^{\circ} \mathrm{C}\right)$, extreme hardness $(8-9$ on the Mohs scale), high chemical and thermal stability, and good thermal and electrical conductivity. It is widely used as coating material in the mechanical industry, as crucibles in the chemical industry, as buffer layers in microelectronics, etc. $[10,11]$. In the present study, the effects of reduction temperature, coal dosage, and reduction time on the phase transformation of titanomagnetite were investigated. Additionally, the separation of metallic iron and TiN was studied.

\section{Materials and Methods}

\subsection{Materials}

The titanomagnetite concentrate used in this study was obtained from Panzhihua, Sichuan Province, China. The particle size distribution of the titanomagnetite concentrate is shown in Table 1. Chemical analyses results are shown in Table 2. X-ray diffraction (XRD, DX-2700, Hao Yuan Instrument Co., Ltd., Dandong, China) analyses revealed that the main crystalline phases of the sample were titanomagnetite $\left(\left(\mathrm{Fe}_{2.5} \mathrm{Ti}_{0.5}\right)_{1.04} \mathrm{O}_{4}\right)$, magnetite $\left(\mathrm{Fe}_{3} \mathrm{O}_{4}\right)$ and ilmenite $\left(\mathrm{FeTiO}_{3}\right)($ Figure 1). The vanadium in the titanomagnetite is the trivalent vanadium $\left(\mathrm{V}^{3+}\right)$ forming a solid solution with the magnetite lattice [2]. The reductant used in this work was anthracite coal. The proximate analysis of the coal was conducted according to China national standards GB/T212-2008 [12], and the results are listed in Table 3 . The coal was ground to $100 \%$ passage through a $0.1 \mathrm{~mm}$ sieve.

Table 1. The particle size distribution of the titanomagnetite concentrate.

\begin{tabular}{cccccccc}
\hline Size $(\mathbf{m m})$ & $\mathbf{+ 0 . 2 8}$ & $\mathbf{0 . 2 8}+\mathbf{0 . 1 5}$ & $\mathbf{- 0 . 1 5 + \mathbf { 0 . 1 0 }}$ & $\mathbf{- 0 . 1 0 + \mathbf { 0 . 0 7 4 }}$ & $\mathbf{- 0 . 0 7 4 + \mathbf { 0 . 0 5 6 }}$ & $\mathbf{- 0 . 0 5 6 + \mathbf { 0 . 0 3 8 }}$ & $\mathbf{- 0 . 0 3 8}$ \\
\hline Content $(\mathrm{wt} \%)$ & 1.27 & 8.16 & 19.50 & 16.90 & 13.54 & 17.61 & 23.02 \\
\hline
\end{tabular}

Table 2. Chemical compositions of the titanomagnetite concentrate (wt \%).

\begin{tabular}{ccccccc}
\hline $\mathbf{F e}$ & $\mathrm{TiO}_{2}$ & $\mathrm{~V}_{\mathbf{2}} \mathbf{O}_{5}$ & $\mathrm{Al}_{2} \mathbf{O}_{3}$ & $\mathbf{M g O}$ & $\mathrm{SiO}_{2}$ & $\mathrm{CaO}$ \\
\hline 56.72 & 10.50 & 0.64 & 2.57 & 1.14 & 3.50 & 0.37 \\
\hline
\end{tabular}


Table 3. Proximate analysis of the coal (air dry, wt \%).

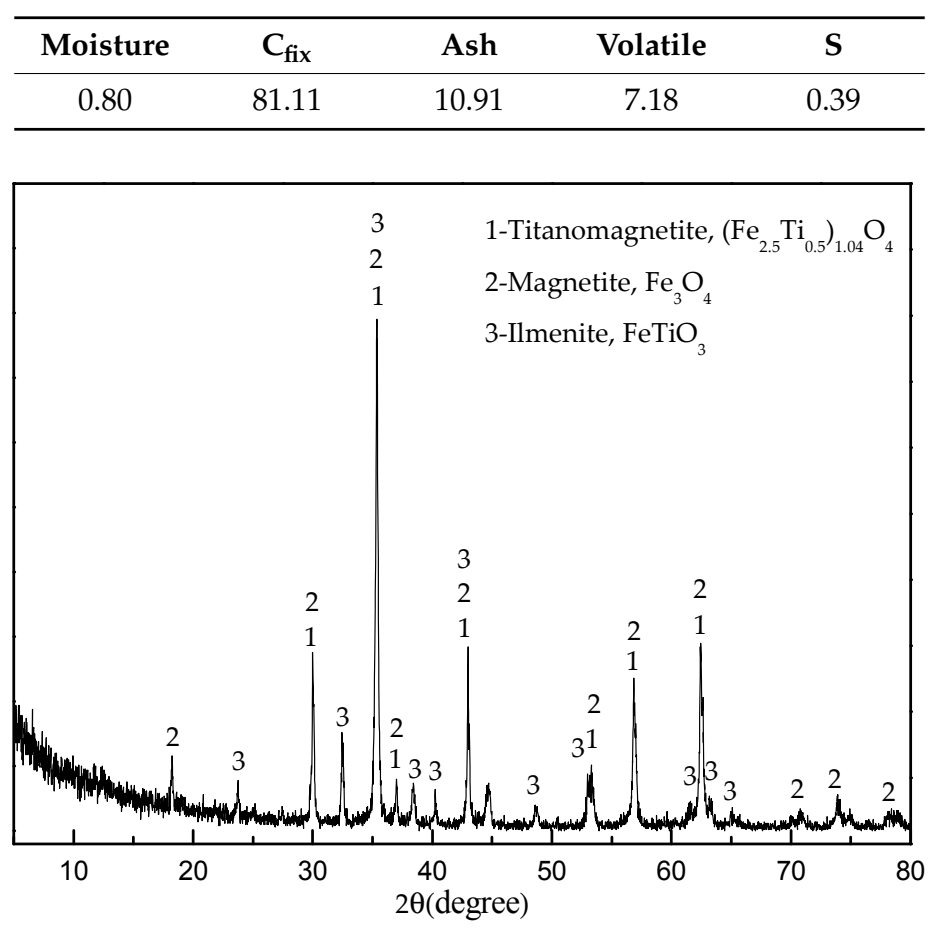

Figure 1. XRD patterns of the titanomagnetite concentrate.

\subsection{Methods}

As a preparation for the reduction experiments, $20 \mathrm{~g}$ of titanomagentite were mixed with coal ( $20 \mathrm{wt} \%, 22 \mathrm{wt} \%, 24 \mathrm{wt} \%, 26 \mathrm{wt} \%, 28 \mathrm{wt} \%$ ), cellulose binder (1 wt \%) and water (about $25 \mathrm{wt} \%$ ) to produce material that could be shaped by hands to make $6-8 \mathrm{~mm}$ diameter pellets. The dosages of coal, binder and water are expressed as percentages that refer to their mass ratios to the titanomagnetite concentrate. An analytical grade of sodium carboxymethylcellulose was employed as a binder. The green pellets were oven dried at $105{ }^{\circ} \mathrm{C}$ for $2 \mathrm{~h}$. The reduction experiments were performed in a muffle furnace under air atmosphere with the following procedures: first, the pellets were placed in the clay-graphite crucible (70 $\mathrm{mm}$ in diameter and $75 \mathrm{~mm}$ in height) with a cap. Then, the crucibles were placed into the furnace and maintained for a certain time (30, 50, 70 and $90 \mathrm{~min}$ ) after the temperature reached the designated temperature $\left(1000,1100,1200,1250,1300\right.$ and $\left.1350{ }^{\circ} \mathrm{C}\right)$. After heating, the crucibles were removed from the furnace and cooled to room temperature under air atmosphere.

After the reduced pellets cooling, they were crushed to $-1 \mathrm{~mm}$ and then treated by two-stage grinding and magnetic separation. Grinding was done using a rod mill (RK/BM-1.0L, Wuhan Rock Crush \& Grind Equipment Manufacture Co., Ltd, Wuhan, China) at $60 \mathrm{wt} \%$ solid density and with a speed of $192 \mathrm{rpm}$. The first stage grinding time was $10 \mathrm{~min}$. A magnetic separator (XCGS-50, Nanchang Li Yuan Mining and Metallurgy Equipment Co., Ltd., Nanchang, China) with a magnetic field intensity of 1080 Oe was used to separate the slurry. The iron concentrates obtained from the first separation were reground for $20 \mathrm{~min}$ to $75.33 \mathrm{wt} \%-0.074 \mathrm{~mm}$ and then magnetically separated using the same conditions.

The resulting magnetic materials were labelled as DRI. The non-magnetic materials obtained from two-stage magnetic separation processes were mixed and labelled as rough TiN concentrates. As a result, DRI and rough TiN concentrates were obtained. The $\mathrm{Fe}, \mathrm{TiO}_{2}$ and $\mathrm{V}_{2} \mathrm{O}_{5}$ contents of the DRI were chemically analyzed, and the composition of the rough TiN concentrates was analyzed by X-ray fluorescence analyser (Axios max, PANalytical, Almelo, The Netherlands). This XRF analyzer 
is a wavelength dispersive spectrometer equipped with Omnian standardless analysis software. The samples were measured as pressed powders.

The recoveries of $\mathrm{Fe}, \mathrm{Ti}$, and $\mathrm{V}$ in the DRI were calculated according to the following formula:

$$
\operatorname{Recovery}(\mathrm{Fe} / \mathrm{Ti} / \mathrm{V})=\frac{\mathrm{Fe} / \mathrm{Ti} / \mathrm{V} \text { content of } \mathrm{DRI} \times \text { Weight of DRI }}{\mathrm{Fe} / \mathrm{Ti} / \mathrm{V} \text { content of titanomagnetic concentrate } \times \text { Weight of titanomagnetic concentrate }} \times 100 \%
$$

\subsection{Characterisation}

XRD with $\mathrm{Cu}-\mathrm{K} \alpha$ radiation and secondary monochromator in the $2 \theta$ range from $5^{\circ}$ to $80^{\circ}$ was used to identify the phases present in the titanomagnetite concentrate and the reduced pellets. SEM and EDS analysis (MLA650F, FEI, Hillsboro, OR, USA) were performed on the samples mounted in epoxy resin, polished, and sputter coated with gold. The electron optical system of SEM consists of the Schottky field emission gun; an acceleration voltage of $0 \sim 30 \mathrm{kV}$; electron images were obtained at an acceleration voltage of $20.0 \mathrm{kV}$ and a working distance of $10.3 \mathrm{~mm}$. A silicon drift detector was employed for the EDS analysis. The EDS results were obtained at an acceleration voltage of $20.0 \mathrm{kV}$ and pulse of $10-15 \mathrm{kcps}$.

\section{Results and Discussion}

\subsection{Effect of Reduction Temperature}

The composite pellets with $26 \mathrm{wt} \%$ coal were reduced over a range of temperatures for $90 \mathrm{~min}$. The phase transformations of the composite pellets were investigated by XRD and the patterns are presented in Figure 2.

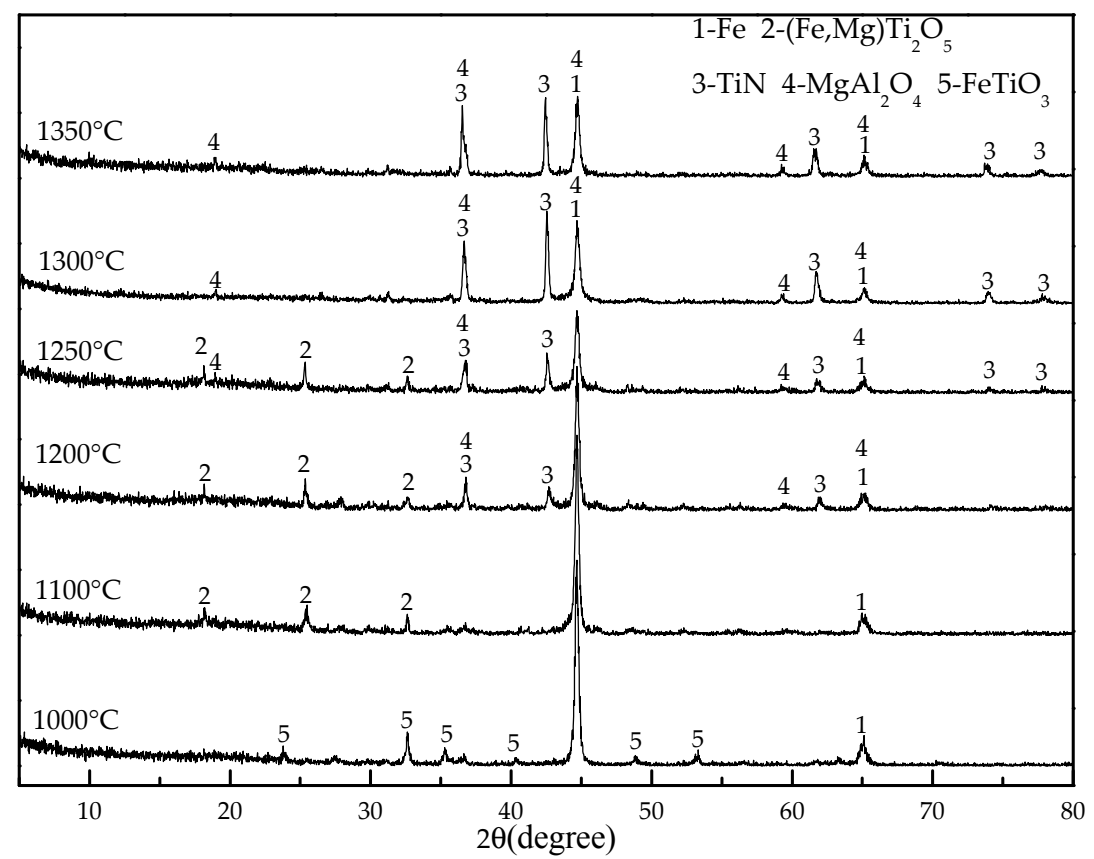

Figure 2. XRD patterns of pellets with $26 \mathrm{wt} \%$ coal reduced over a range of temperatures for $90 \mathrm{~min}$.

Figure 2 shows that the main phases of the pellets reduced at $1000{ }^{\circ} \mathrm{C}$ were metallic iron and $\mathrm{FeTiO}_{3}$. As the reduction temperature increased to $1100{ }^{\circ} \mathrm{C}$, the diffraction peaks of $\mathrm{FeTiO}_{3}$ disappeared and peaks of magnesium titanium oxide $\left((\mathrm{Fe}, \mathrm{Mg}) \mathrm{Ti}_{2} \mathrm{O}_{5}\right)$ were observed. When temperature is elevated to $1200{ }^{\circ} \mathrm{C}$, in addition to $\mathrm{Fe}$ and $\mathrm{MgTi}_{2} \mathrm{O}_{5}$, a small amount of TiN begins to form, and magnesium aluminate spinel $\left(\mathrm{MgAl}_{2} \mathrm{O}_{4}\right)$ was observed. This result implies that the formation of metallic iron is easier than the formation of TiN during the carbothermal reduction process. As the 
temperature increased to $1300{ }^{\circ} \mathrm{C}$, the peaks of $(\mathrm{Fe}, \mathrm{Mg}) \mathrm{Ti}_{2} \mathrm{O}_{5}$ disappeared, and the peaks of $\mathrm{TiN}$ increased significantly. No other titanium-bearing phases were found. Hence, most of the titanium oxides were likely reduced to TiN under these conditions. Further increasing the reduction temperature to $1350{ }^{\circ} \mathrm{C}$ did not obviously alter the phases. Therefore, the reduction temperature was fixed at $1300^{\circ} \mathrm{C}$ in the subsequent experiments.

\subsection{Effect of Coal Dosage}

Coal dosage is a highly important parameter affecting the reduction of titanomagnetite concentrate. Thus, the effects of coal dosage on phase transitions in pellets were investigated by XRD. The coal dosage varied from $20 \mathrm{wt} \%$ to $28 \mathrm{wt} \%$. The reduction temperature was $1300{ }^{\circ} \mathrm{C}$, and the reduction time was $90 \mathrm{~min}$. The results are shown in Figure 3.

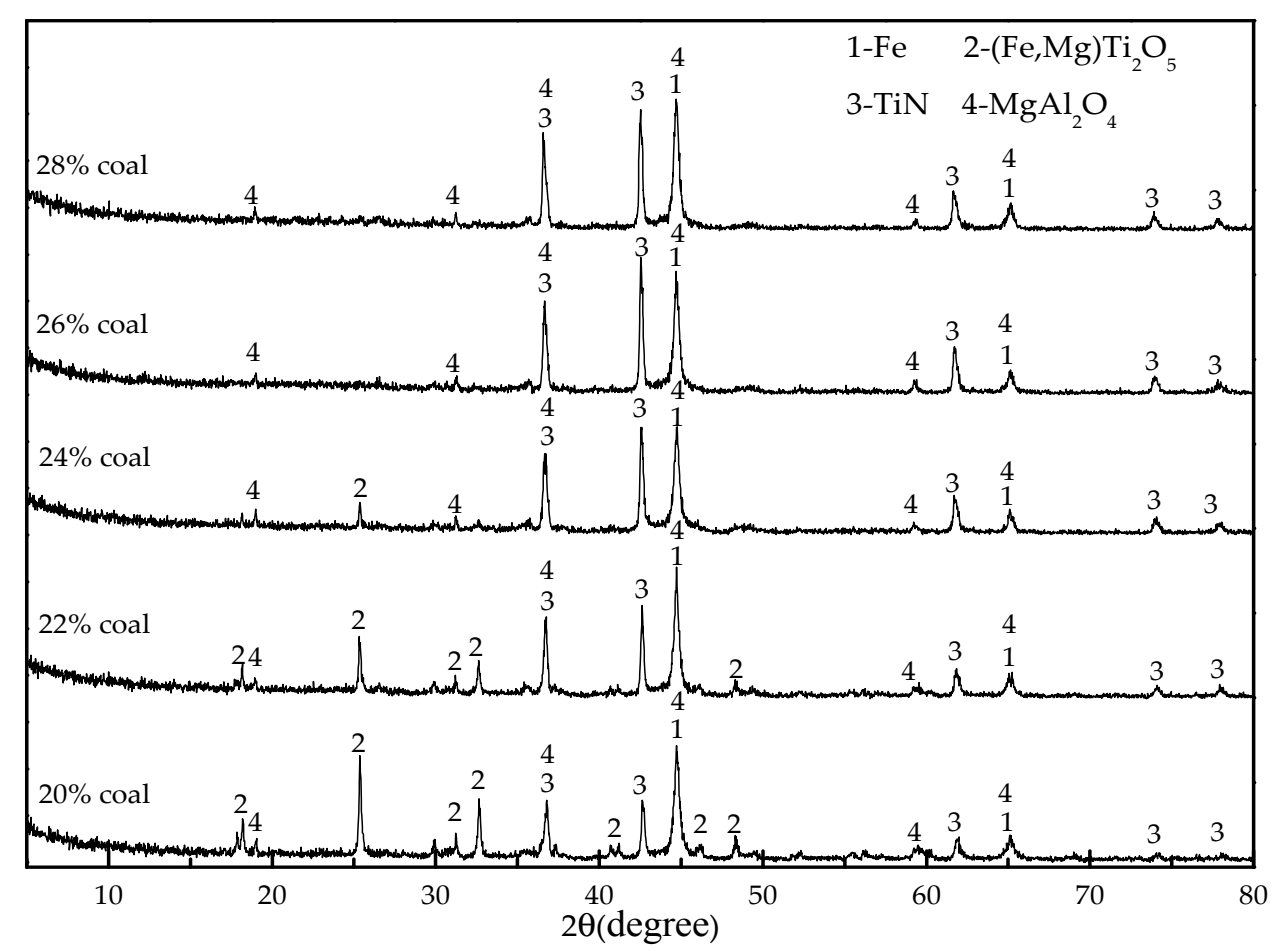

Figure 3. XRD patterns of pellets with different coal dosage reduced at $1300{ }^{\circ} \mathrm{C}$ after $90 \mathrm{~min}$.

When $20 \mathrm{wt} \%$ coal was added, the reduced pellets consisted of metallic iron, $\mathrm{TiN},(\mathrm{Fe}, \mathrm{Mg}) \mathrm{Ti}_{2} \mathrm{O}_{5}$, and $\mathrm{MgAl}_{2} \mathrm{O}_{4}$ (Figure 3). By increasing the coal dosage from $20 \mathrm{wt} \%$ to $26 \mathrm{wt} \%$, the peaks of $(\mathrm{Fe}, \mathrm{Mg}) \mathrm{Ti}_{2} \mathrm{O}_{5}$ decreased and the peaks of TiN increased. These results indicate that increasing coal dosage facilitates TiN formation. Further increasing the coal dosage to $28 \mathrm{wt} \%$ did not substantially alter the phases. Therefore, a coal dosage of $26 \mathrm{wt} \%$ was selected.

\subsection{Effect of Reduction Time}

Studies on the effects of reduction time on the reduction of composite pellets were conducted at $1300{ }^{\circ} \mathrm{C}$, and the coal dosage was fixed at $26 \mathrm{wt} \%$. The results are presented in Figure 4 . The reduction time significantly affected TiN formation. When the reduction time was $30 \mathrm{~min}$, the main phases of the reduced pellets were $\mathrm{Fe},(\mathrm{Fe}, \mathrm{Mg}) \mathrm{Ti}_{2} \mathrm{O}_{5}, \mathrm{TiN}$, and $\mathrm{MgAl}_{2} \mathrm{O}_{4}$. As the reaction time was prolonged, the peaks of TiN increased, whereas the peaks of $(\mathrm{Fe}, \mathrm{Mg}) \mathrm{Ti}_{2} \mathrm{O}_{5}$ decreased. As the reaction time extended to $90 \mathrm{~min}$, the peaks of $(\mathrm{Fe}, \mathrm{Mg}) \mathrm{Ti}_{2} \mathrm{O}_{5}$ disappeared. These observations imply that titanium was almost completely transformed into TiN. Thus, the reduction time was fixed at $90 \mathrm{~min}$. 


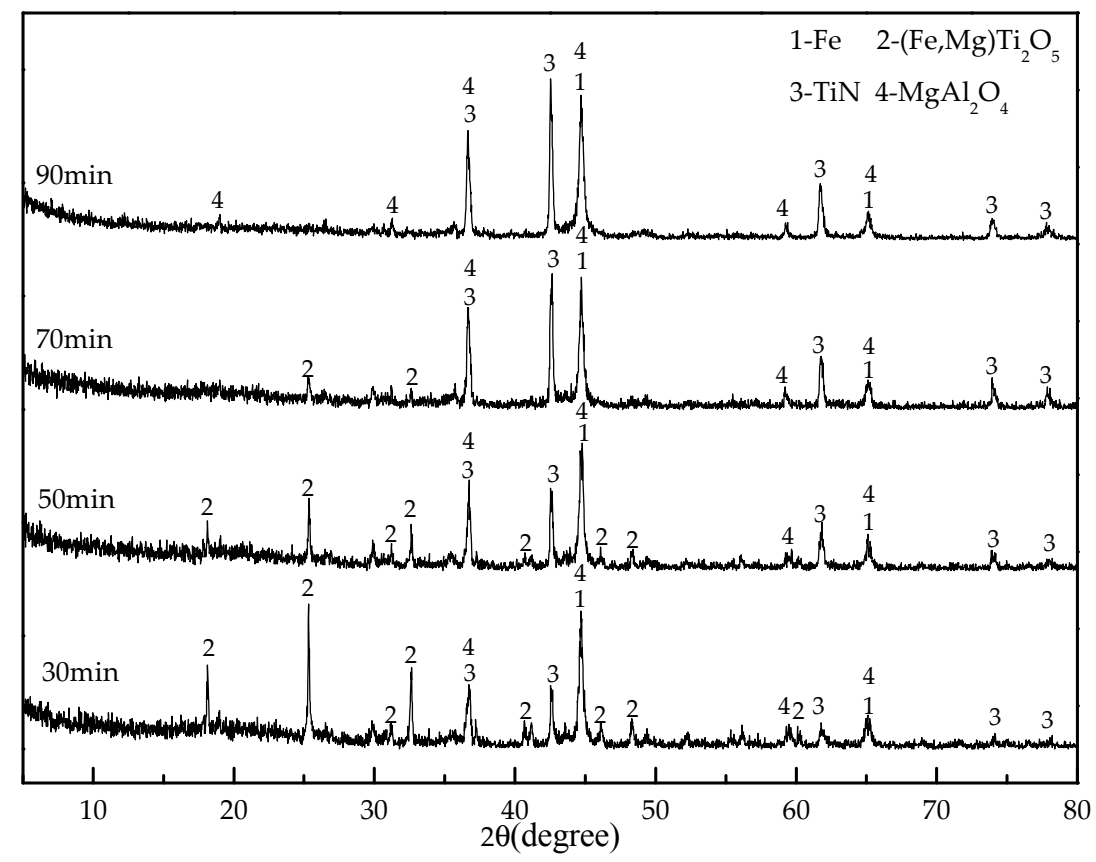

Figure 4. XRD patterns of pellets with $26 \mathrm{wt} \%$ reduced at $1300{ }^{\circ} \mathrm{C}$ after different time.

Based on the experimental results above, it can be summarized that the formation of titanium nitride is much more difficult than that of metallic iron during the process of carbothermal reduction of titaniummagnetite. It requires higher reduction temperature, more reducing agent and longer reduction time. Many scholars have studied the carbothermal reduction process of titaniummagnetite, titanium generally existed in the forms of $\mathrm{FeTiO}_{3},(\mathrm{Fe}, \mathrm{Mg}) \mathrm{Ti}_{2} \mathrm{O}_{5}$, and $\mathrm{TiO}_{2}$ rather than $\mathrm{TiN}$ in the reduced products as reported $[4,5,13,14]$. This may be due to the fact that these experiments were carried out at the conditions of relatively lower temperature, lack of sufficient reducing agent and sufficient reduction time.

The carbothermic reduction process for synthesizing $\mathrm{TiN}$ and $\mathrm{Fe}$ from $\mathrm{FeTiO}_{3}$ is a very complex process which involves a series of intermediate reactions. The overall carbothermal reduction reaction of ilmenite to TiN and Fe is given as follows [15,16]:

$$
\mathrm{FeTiO}_{3}+3 \mathrm{C}+1 / 2 \mathrm{~N}_{2}(\mathrm{~g})=\mathrm{Fe}+\mathrm{TiN}+3 \mathrm{CO}(\mathrm{g})
$$

Ilmenite was generally believed to first reduce to $\mathrm{Fe}$ and $\mathrm{TiO}_{2}$. Afterward, $\mathrm{TiO}_{2}$ was gradually reduced to sub-oxides, such as $\mathrm{Ti}_{9} \mathrm{O}_{17}, \mathrm{Ti}_{4} \mathrm{O}_{7}, \mathrm{Ti}_{4} \mathrm{O}_{7}, \mathrm{Ti}_{3} \mathrm{O}_{5}$, and then to N-, C- and O-containing phases $\mathrm{TiN}_{x} \mathrm{C}_{y} \mathrm{O}_{1-x-y}(x+y \leq 1 ; x, y \geq 0)$. TiN $\mathrm{C}_{y} \mathrm{O}_{1-x-y}$ was finally transformed into TiN as $\mathrm{O}$ was removed and $\mathrm{C}$ was replaced by $\mathrm{N}$ [16]. In the present study, no intermediate phases except $(\mathrm{Fe}, \mathrm{Mg}) \mathrm{Ti}_{2} \mathrm{O}_{5}$ $\left(\mathrm{Ti}_{3} \mathrm{O}_{5}\right.$-type compound) were detected in the reduced pellets, probably because of these intermediate phases were unstable.

\subsection{Microstructure of the Reduced Composite Pellets}

The SEM image and the EDS results of the composite pellets with $26 \mathrm{wt} \%$ reduced at $1300{ }^{\circ} \mathrm{C}$ for $90 \mathrm{~min}$ are displayed in Figure 5. 


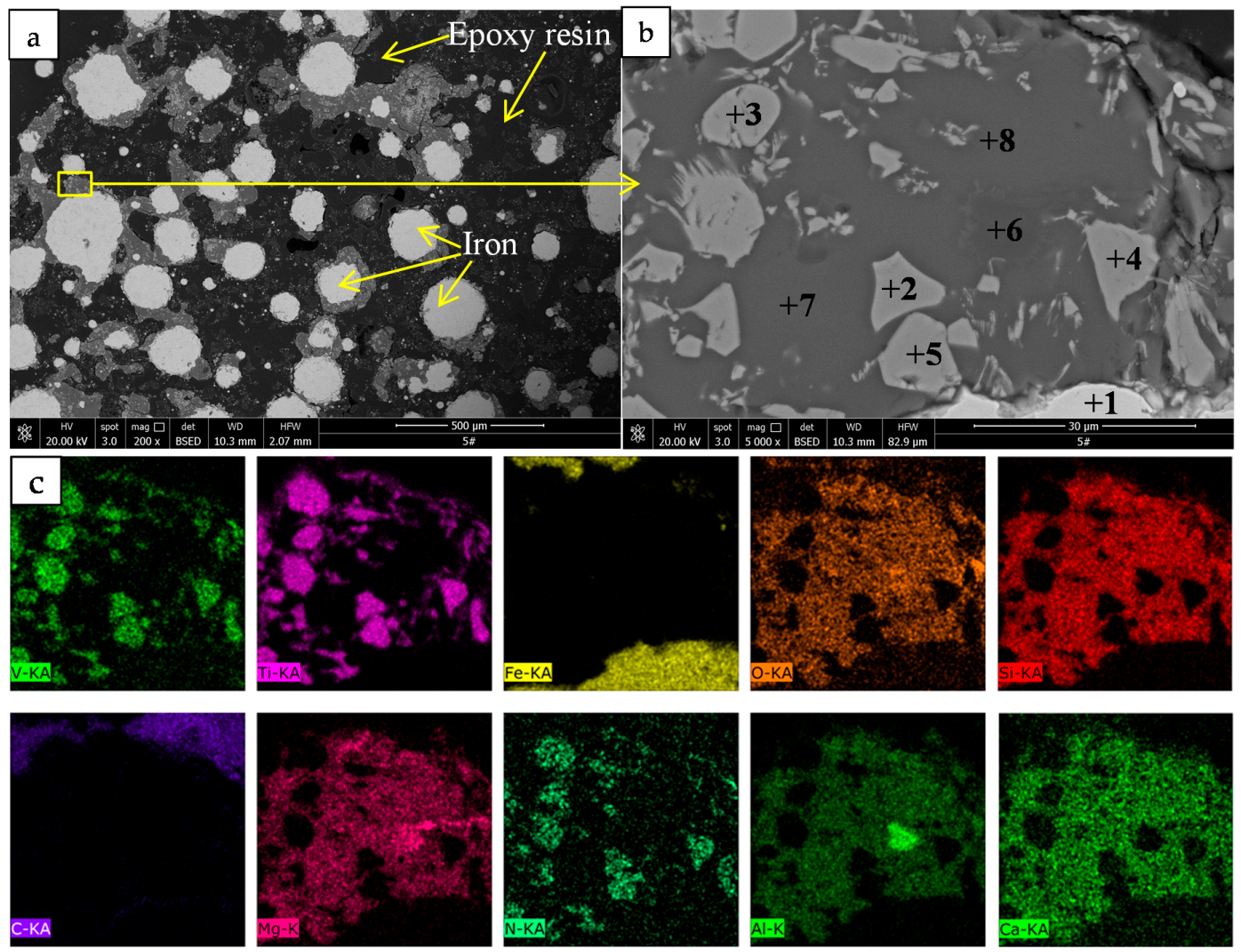

Figure 5. SEM images and elemental surface scanning images of the pellets with $26 \mathrm{wt} \%$ coal reduced at $1300{ }^{\circ} \mathrm{C}$ for $90 \mathrm{~min}$ : (a) SEM images $(200 \times)$; (b) partial enlarged view of the $(\mathbf{a})(5000 \times)$, " + " refer to analyzed point by EDS, numbers refer to composition data in Table 4; (c) elemental surface scanning images of the area showed in (b), K and KA are electron orbital labels.

Table 4. Chemical composition of points indicated in Figure $5 \mathrm{~b}$ (wt \%).

\begin{tabular}{cccccccccccccc}
\hline Point & $\mathbf{C}$ & $\mathbf{N}$ & $\mathbf{O}$ & $\mathbf{N a}$ & $\mathbf{M g}$ & $\mathbf{A l}$ & $\mathbf{S i}$ & $\mathbf{S}$ & $\mathbf{C a}$ & $\mathbf{T i}$ & $\mathbf{V}$ & $\mathbf{F e}$ & Phase \\
\hline 1 & 8.61 & $-*$ & - & - & - & - & 0.61 & - & - & 0.29 & - & 90.49 & Iron \\
2 & 2.06 & 14.73 & - & - & - & - & - & - & 0.20 & 80.26 & 2.19 & 0.55 & $\mathrm{TiN}$ \\
3 & 4.25 & 17.07 & 3.00 & - & - & - & - & - & 0.18 & 68.32 & 7.18 & - & $\mathrm{TiN}$ \\
4 & 1.15 & 12.38 & - & - & - & - & - & - & 0.34 & 82.94 & 2.62 & 0.56 & $\mathrm{TiN}$ \\
5 & 1.85 & 13.80 & 1.73 & - & - & - & - & - & 0.15 & 79.43 & 2.03 & 1.02 & $\mathrm{TiN}$ \\
6 & 6.12 & - & 44.43 & - & 14.62 & 31.52 & - & - & - & 2.94 & 0.13 & 0.23 & Spinel \\
7 & 6.62 & - & 45.36 & 0.76 & 10.78 & 9.57 & 16.16 & 0.91 & 7.41 & 2.15 & - & 0.28 & Slag \\
8 & 5.78 & - & 46.17 & 0.61 & 10.85 & 9.36 & 15.99 & 0.74 & 7.97 & 2.19 & - & 0.33 & Slag \\
\hline \multicolumn{8}{c}{ * Not detected. }
\end{tabular}

It can be seen from Figure 5a that near-spherical metallic iron particles with diameters from dozens of microns to about $300 \mu \mathrm{m}$ were formed, whereas irregular TiN particles have particle sizes generally less than $10 \mu \mathrm{m}$ (Figure 5b). Furthermore, the metallic iron and TiN did not form a close relationship, which is conducive to the separation process.

The surface scanning results from Figure 5c show that elemental distributions of titanium, vanadium and nitrogen in the observed area were strongly correlated, and that the point analysis results from Table 4 reveal that the TiN phase contains 2 wt \% 7 wt \% V and 1 wt $\% \sim 4$ wt $\%$ C. These results indicate that a small amount of $\mathrm{V}$ and $\mathrm{C}$ were dissolved in the TiN phase. The reduction of vanadium oxides occurs more readily than reduction of titanium oxides [4]. Considering the fact that 
titanium oxides has been reduced and nitrided to TiN under the present conditions, vanadium oxides should also be reduced and transformed to nitride or carbide according to the following reactions [17].

$$
\begin{gathered}
\mathrm{V}_{2} \mathrm{O}_{3}+3 \mathrm{C}+\mathrm{N}_{2}(\mathrm{~g})=2 \mathrm{VN}+3 \mathrm{CO}(\mathrm{g}) \\
\mathrm{V}_{2} \mathrm{O}_{3}+5 \mathrm{C}=2 \mathrm{VC}+3 \mathrm{CO}(\mathrm{g})
\end{gathered}
$$

$\mathrm{TiN}, \mathrm{TiC}, \mathrm{VC}, \mathrm{VN}$ possess the same $\mathrm{NaCl}$-type structures, and the atomic radius of $\mathrm{C}$ is similar to that of $\mathrm{N}$, as well as that of $\mathrm{V}$ to that of $\mathrm{Ti}[11,17,18]$. These elements can form a continuous solid solution. Strictly speaking, therefore, the prepared TiN should be (Ti,V) (N,C). The introduction of carbon and vanadium is beneficial in improving the properties of titanium nitride materials [11,18,19]. Moreover, traces of $\mathrm{O}, \mathrm{Fe}$ and $\mathrm{Ca}$ were also detected in the TiN phase.

Table 4 also shows that the $\mathrm{Fe}, \mathrm{Ti}, \mathrm{V}$ contents of the slag and spinel were very low, indicating that the reduction of iron oxides, titanium oxides, and vanadium oxides in slag phase proceed close to complete under the present conditions.

\subsection{Separation of Metallic Iron and TiN}

The pellets with 26 wt \% coal reduced at $1300{ }^{\circ} \mathrm{C}$ for 90 min were subjected to grinding and magnetic separation. The results are presented in Table 5.

Table 5. Production index of DRI.

\begin{tabular}{ccc}
\hline Element & Content in DRI (wt \%) & Recovery (wt \%) \\
\hline $\mathrm{Fe}$ & 92.88 & 92.85 \\
$\mathrm{Ti}$ & 1.00 & 9.00 \\
$\mathrm{~V}$ & 0.13 & 19.40 \\
\hline
\end{tabular}

Table 5 shows that the DRI contained 92.88 wt $\% \mathrm{Fe}, 1.00 \mathrm{wt} \% \mathrm{Ti}$, and $0.13 \mathrm{wt} \% \mathrm{~V}$, and the recoveries of $\mathrm{Fe}, \mathrm{Ti}$, and $\mathrm{V}$ in the DRI were $92.85 \mathrm{wt} \%, 9.00 \mathrm{wt} \%$, and $19.40 \mathrm{wt} \%$, respectively. Consequently, the $\mathrm{Ti}$ and $\mathrm{V}$ enrichment in the rough TiN concentrate were calculated to be $91.00 \mathrm{wt} \%$ and $80.60 \mathrm{wt} \%$, respectively, on the basis of mass balance. These results reveal that metallic iron and TiN can be separated precisely through the grinding-magnetic separation process. The chemical compositions of the rough TiN concentrate are given in Table 6. Further study to refine the rough TiN concentrate is in progress based on the difference in properties between TiN and gangue, such as specific gravity, magnetic, floatability, and acid resistance.

Table 6. Chemical compositions of the rough TiN concentrate (wt \%), as determined by XRF analysis.

\begin{tabular}{cccccccccc}
\hline $\mathrm{Ti}$ & $\mathrm{Fe}$ & $\mathrm{V}_{\mathbf{2}} \mathrm{O}_{5}$ & $\mathrm{SiO}_{2}$ & $\mathrm{Al}_{2} \mathrm{O}_{3}$ & $\mathrm{MgO}$ & $\mathrm{CaO}$ & $\mathrm{MnO}$ & $\mathrm{Na}_{2} \mathrm{O}$ & $\mathrm{S}$ \\
\hline 20.21 & 9.15 & 1.11 & 11.85 & 10.07 & 7.96 & 3.51 & 0.66 & 0.41 & 1.48 \\
\hline
\end{tabular}

\section{Conclusions}

The following conclusions can be drawn from the current study:

(1) The conversion of titanium to TiN is significantly affected by reduction temperature, reduction time, and coal dosage. Increasing the reduction temperature, reduction time, and coal dosage can promote the formation of TiN. Under the optimum conditions of $1300{ }^{\circ} \mathrm{C}$ reduction temperature, $26 \mathrm{wt} \%$ coal dosage and 90 min reduction time, titanium was almost completely transformed into TiN.

(2) The SEM analysis showed that near-spherical metallic iron particles with diameters from dozens of microns to about $300 \mu \mathrm{m}$ were formed in the reduced pellets. By contrast, the TiN particles 
were generally less than $10 \mu \mathrm{m}$. The EDS results revealed that the TiN phase contains a certain amount of vanadium and carbon, and traces of other impurities.

(3) The separation results revealed metallic iron and TiN can be precisely separated through the grinding-magnetic separation process.

Acknowledgments: This work was supported by the National Natural Science Foundation of China (Grant No. 51704129), Natural Science Foundation of Jiangxi Province, China (20171BAB216021), Foundation of Jiangxi Educational Committee, China (No. GJJ150624, No. GJJ150616) and Doctoral Scientific Research Foundation of Jiangxi University of Science and Technology, China (No. JXXJBS16004).

Author Contributions: Tingshen Qiu and Wen Yu conceived and designed the experiments; Xiaojin Wen, Yuechao Tian, Jiali $\mathrm{Fu}$ and Weiqin Huang performed the experiments; Jiangan Chen analyzed the data; Jingzhong Kuang and Qiongyao Tang contributed reagents/materials/analysis tools; Wen Yu wrote the paper.

Conflicts of Interest: The authors declare no conflict of interest.

\section{References}

1. Zheng, F.; Chen, F.; Guo, Y.; Jiang, T.; Travyanov, A.Y.; Qiu, G. Kinetics of hydrochloric acid leaching of titanium from titanium-bearing electric furnace slag. JOM 2016, 68, 1476-1484. [CrossRef]

2. Du, H. Principle of Blast Furnace Smelting of Vanadium-Bearing Titanomagnetite; Metallurgical Industry Press: Beijing, China, 1996; p. 8. ISBN 9787030051189. (In Chinese)

3. Wang, H.; Zhang, Y.; An, Z.; Zhao, S. Hydrometallurgical process for recovering titanium from titanium-bearing blast furnace slag in Panzhihua Steel Plant. Nonferr. Metal. Sci. Eng. 2016, 7, 21-24. (In Chinese) [CrossRef]

4. Zhao, L.; Wang, L.; Chen, D.; Zhao, H.; Liu, Y.; Qi, T. Behaviors of vanadium and chromium in coal-based direct reduction of high-chromium vanadium-bearing titanomagnetite concentrates followed by magnetic separation. Trans. Nonferr. Met. Soc. 2015, 25, 1325-1333. [CrossRef]

5. Zhao, L.; Wang, L.; Qi, T.; Chen, D.; Zhao, H.; Liu, Y. A novel method to extract iron, titanium, vanadium, and chromium from high-chromium vanadium-bearing titanomagnetite concentrates. Hydrometallurgy 2014, 149, 106-109. [CrossRef]

6. Sun, Y.; Zheng, H.; Dong, Y.; Jiang, X.; Shen, Y.; Shen, F. Melting and separation behavior of slag and metal phases in metallized pellets obtained from the direct-reduction process of vanadium-bearing titanomagnetite. Int. J. Miner. Process. 2015, 142, 119-124. [CrossRef]

7. Jiang, T.; Wang, S.; Guo, Y.; Chen, F.; Zheng, F. Effects of basicity and $\mathrm{MgO}$ in slag on the behaviors of smelting vanadium titanomagnetite in the direct reduction-electric furnace process. Metals 2016, 6, 107. [CrossRef]

8. Zhang, G.; Feng, K.; Yue, H. Theoretical analyses and experimental investigations of selective carbothermal reactions of vanadium-bearing titanomagnetite concentrates for preparation of iron-based wear-resistant material. JOM 2016, 68, 2525-2532. [CrossRef]

9. Wu, E.; Zhu, R.; Yang, S.; Li, H.; Li, J.; Hou, J. Preparation of Fe-Ti(C,N) composites from titanomagnetite concentrate by carbothermal reduction in air atmosphere. Iron Steel Vanadium Titanium 2016, 37, 46-50. (In Chinese) [CrossRef]

10. Yang, X.; Li, C.; Yang, L.; Yan, Y.; Qian, Y. Reduction-nitridation synthesis of titanium nitride nanocrystals. J. Am. Ceram. Soc. 2003, 86, 206-208. [CrossRef]

11. Pierson, H.O. Handbook of Refractory Carbides \& Nitrides: Properties, Characteristics, Processing and Apps; Noyes Publications: Park Ridge, NJ, USA, 1996; p. 193. ISBN 081551770X.

12. China Technical Committee for Standardization. GB/T 212-2008 Proximate Analysis of Coal; Standards Press of China: Beijing, China, 2008. (In Chinese)

13. Sun, H.; Dong, X.; She, X.; Xue, Q.; Wang, J. Solid state reduction of titanomagnetite concentrate by graphite. ISIJ Int. 2013, 53, 564-569. [CrossRef]

14. Chen, D.; Song, B.; Wang, L.; Qi, T.; Wang, Y.; Wang, W. Solid state reduction of Panzhihua titanomagnetite concentrates with pulverized coal. Miner. Eng. 2011, 24, 864-869. [CrossRef]

15. Welham, N.J.; Willis, P.E. Formation of TiN/TiC-Fe composites from ilmenite $\left(\mathrm{FeTiO}_{3}\right)$ concentrate. Metall. Mater. Trans. B 1998, 29, 1077-1083. [CrossRef] 
16. Ru, J.; Hua, Y.; Xu, C.; Zhang, Q.; Wang, D.; Gong, K. Synthesis of TiN from $\mathrm{FeTiO}_{3}$ by microwave-assisted carbothermic reduction-nitridation. J. Alloys Compd. 2014, 583, 121-127. [CrossRef]

17. Wu, Y.; Zhang, G.; Chou, K. A novel process to synthesize high-quality ferrovanadium nitride. Metall. Mater. Trans. B 2016, 47, 3405-3412. [CrossRef]

18. Kiesler, D.; Bastuck, T.; Theissmann, R.; Kruis, F.E. Plasma synthesis of titanium nitride, carbide and carbonitride nanoparticles by means of reactive anodic arc evaporation from solid titanium. J. Nanopart. Res. 2015, 17, 152. [CrossRef]

19. Dong, S.; Chen, X.; Gu, L.; Zhou, X.; Wang, H.; Liu, Z.; Han, P.; Yao, J.; Wang, L.; Cui, G. TiN/VN composites with core/shell structure for supercapacitors. Mater. Res. Bull. 2011, 46, 835-839. [CrossRef]

2017 by the authors. Licensee MDPI, Basel, Switzerland. This article is an open access article distributed under the terms and conditions of the Creative Commons Attribution (CC BY) license (http://creativecommons.org/licenses/by/4.0/). 